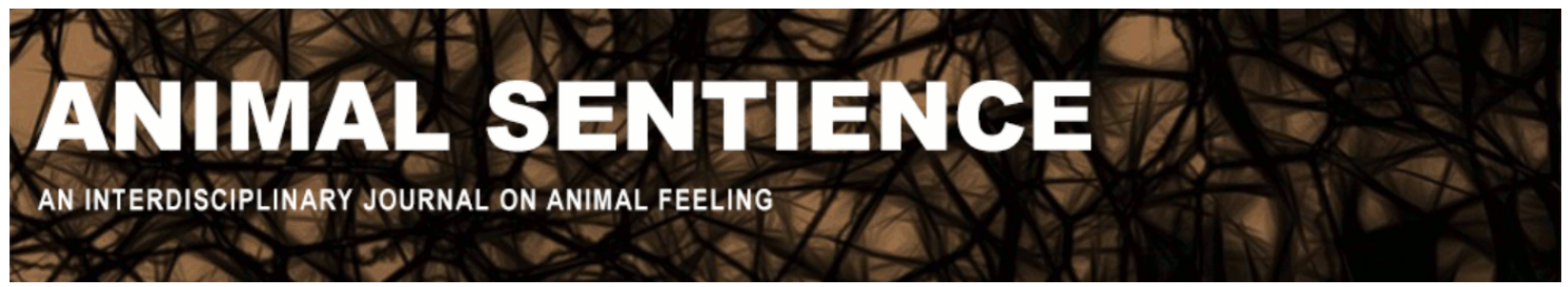

Lee, Kelley (2020) Rethinking global governance to address zoonotic disease risks: Connecting the dots. Animal Sentience 30(19)

DOI: $10.51291 / 2377-7478.1648$

Date of submission: 2020-09-28

Date of acceptance: $2020-09-28$

(c) $\underset{\mathrm{EY}}{\mathrm{C}}$

This article has appeared in the journal Animal

Sentience, a peer-reviewed journal on animal

cognition and feeling. It has been made open access,

free for all, by WellBeing International and deposited

in the WBI Studies Repository. For more information,

please contact

wbisr-info@wellbeingintl.org.

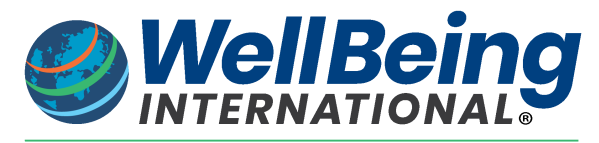

SOLUTIONS FOR PEOPLE, ANIMALS AND ENVIRONMENT 


\title{
Rethinking global governance to address zoonotic disease risks: Connecting the dots
}

Commentary on Wiebers \& Feigin on Covid Crisis

\author{
Kelley Lee \\ Faculty of Health Sciences, Simon Fraser University
}

\begin{abstract}
Large-scale changes in human behaviour are urgently needed to prevent future pandemics involving zoonotic diseases such as COVID-19. However, this will not happen to the required degree, and with sufficient speed, without a major shift in how humanity collectively governs itself. Alongside a shift in focus from individual behaviours to the structural conditions underpinning the world economy that shape human behaviours, effective global governance presses us to connect more dots than ever before. The One Health approach is an important starting point but we need to go much further.
\end{abstract}

Kelley Lee is a Tier 1 Canada Research Chair in Global Health Governance and Professor of Global Health Policy in the Faculty of Health Sciences, Simon Fraser University, Canada. Her work focuses on strengthening collective action to mitigate the adverse impacts of globalization on population health and disease. Website

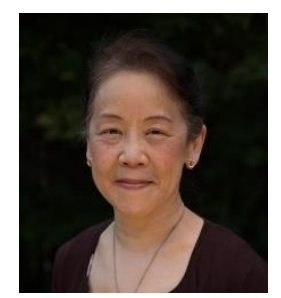

The large-scale impacts of public health emergencies, such as the COVID-19 pandemic, are rare opportunities to harness collective thinking about what went wrong and what we need to change to do better. While many minds are understandably focused on figuring out how to get out of this mess, in the immediate term, Wiebers \& Feigin (2020) (W\&F) rightfully encourage us to pay sharp attention to the short-term past and longer-term future. They point to a troubling confluence of human-caused factors - overconsumption of animal proteins, intense animal rearing practices, mistreatment of wild animals, and habitat destruction - all coming back to roost in the form of a deadly zoonotic disease. This is certainly not the first time. Indeed, the overall number and the disease richness (number of unique diseases) of infectious disease outbreaks since 1980 has increased significantly, with zoonotic diseases dominating this trend (Smith et al., 2014). COVID-19 is thus another warning for humanity "to rethink our relationship with all life on this planet," as W\&F argue, given the "oneness of all that exists." So how do we ensure that we heed this new warning as a critical opportunity for change?

Our first task is to refocus efforts, from trying to change individual behaviours to addressing the societal structures that shape those behaviours. It is completely true and right that the exploitation and mistreatment of wild and domesticated animals and their habitats must stop. However, the scale of the changes that are urgently needed will not be achieved by pleading, cajoling or shaming individuals. Like health promotion efforts focused solely on modifiable behavioural risk factors such as smoking and lack of physical activity, failing to address the upstream causes of undesirable behaviours will yield limited results (Lee and Crosby, 2019). For example, the capturing of wild animals and selling them as "bush meat" occurs, in large part, because of the lack of alternative food sources and income. This is not a lifestyle choice but a strategy for eking out a subsistence-level income, albeit in an unsustainable way. These stark 
choices, in turn, exist because of a highly inequitable world economy which keeps a large proportion of humanity in perpetual grinding poverty. Importantly, it is this same world economy that encourages the wealthy minority to overconsume mass-produced animal proteins. Both poor and rich, in other words, co-exist within a globalized food system controlled by huge and hugely profitable transnational companies. If we want to change what people eat and how it is produced, we need to critically interrogate a system which has reduced animals and humans to commodities and consumers respectively.

This leads to our second task - building the global institutions urgently needed to address what Florini and Sharma (2020) call "systemic hazards". They argue that the acceleration and intensification of economic globalization since the 1980s has resulted in "increasing fragility in our political, social, economic, and financial orders." For producers, wealth creation has been achieved, for example, through greater economies of scale, cheaper labour costs and ready access to natural resources. For consumers, the appetite for more products at lower prices has fuelled worldwide market demand. Less visible, perhaps, are the global governance institutions that sustain these supply and demand behaviours. Governance is about the rules and processes by which a society steers itself towards collective goals. If we wish to shift the goals from wealth generation to stewardship of the planet in sustainable ways then the carrots and sticks embedded within global governance needs to change fundamentally. In other words, we have systems of global governance which reward behaviours that are contributing to planetary destruction. The carrots and sticks built into the system do not encourage behaviours that are sustainable. Change the way rewards and punishments are dolled out, and we change our collective fate.

Building on the commentaries by Fox (2020) and Fawcett (2020), the One Health or One Welfare approach is a critical starting point. But we need to go further. Economic governance is currently elevated far above environmental or health governance. Moreover, environmental or health governance is designed in ways that protect economic governance. The purpose of the International Health Regulations, administered by the World Health Organization, is "to prevent, protect against, control and provide a public health response to the international spread of disease in ways that... avoid unnecessary interference with international traffic and trade" (WHO, 2005). On paper, policy makers mediate among diverse interests and public policy goals. In practice, powerful economic interests have fended off regulation as incursions on their capacity to generate wealth even if it means substantial environmental or health costs.

What COVID-19 is teaching us, however, is that even powerful economic interests are not best served by a world unable to cope with systemic hazards. The current pandemic is a loselose scenario and thus a rare opportunity to connect more dots across policy spheres. The largescale clearing of the world's rainforests by cattle ranchers and palm oil producers are contributing to the risks of zoonotic diseases by bringing human and other animals species in closer proximity. The transnational corporations sheltered in overseas havens to minimize corporate tax liabilities have financially kneecapped the government revenues used to build health systems, fund WHO and other disease surveillance systems, and uphold environmental protections. Short-term selfenrichment, at the expense of the public infrastructure and the natural environments upon which firms are also dependent to operate, is hardly a sound business strategy. If a ship without lifeboats is sinking, it doesn't matter if you are in first class or steerage. Everyone is going down. 
In conclusion, approaches such as One Health, Planetary Health and complex systems are all moving us in the right direction towards connecting the intersecting dots within and across contemporary societies and the natural environment. Efforts to address global scale threats are not well-served by reductionist thinking and fragmented institutional responses. COVID-19 offers a rare opportunity to see these interconnections and disrupt embedded ways of thinking that constrain effective collective action. It may not feel like it, but we have been given a gift. We cannot afford to squander it.

\section{References}

Fawcett, Anne (2020) One Welfare, the role of health professionals, and climate change. Animal Sentience, 30(9).

Florini A, Sharma S. Reckoning with systemic hazards. Finance and Development 2020; 57(2): 48-51.

Fox, Michael W. (2020) One planet, one health. Animal Sentience, 30(6).

Hale, Thomas \& Held, David (2017) Beyond Gridlock. London: Polity Press.

Lee, Kelley \& Crosbie, Eric (2020). Understanding Structure and Agency as Commercial Determinants of Health. International Journal of Health Policy and Management, 9(7): 315-318.

Smith, K., Goldberg, M., Rosenthal, S., Carlson L., Chen, J., Chen, C., Ramachandran, S. (2014) Global rise in human infectious disease outbreaks. Journal of the Royal Society Interface, 11(101):20140950.

Wiebers, David and Feigin, Valery (2020) What the COVID-19 crisis is telling humanity. Animal Sentience 30(1). 